\title{
REKONSEPTUALISASI PENYIDIKAN TINDAK PIDANA KORUPSI OLEH POLRI DALAM RANGKA EFEKTIFITAS PEMBERANTASAN TINDAK PIDANA KORUPSI
}

\author{
M. Aris Purnomo1, Eko Soponyono ${ }^{2}$ \\ Program Studi Magister Ilmu Hukum \\ Fakultas Hukum Universitas Diponegoro \\ eko.soponyono@gmail.com
}

\begin{abstract}
ABSTRAK
Korupsi telah menjadi bagian dari kehidupan, menjadi suatu sistem dan menyatu dengan penyelenggaraan pemerintah negara. Dampak yang ditimbulkan oleh korupsi, bukan saja kerugian dari aspek ekonomi, tetapi hampir semua aspek kehidupan dipengaruhi baik sosial, budaya, politik dan keamanan. Penelitian ini bertujuan untuk mengetahui dan memahami Konsep penyidikan tindak pidana korupsi oleh Kepolisian negara Republik Indoneisa, dan mengetahui konsep penyidikan tindak pidana korupsi yang ideal di masa akan datang. Hasil penelitian menunjukkan bahwa konsep penyidikan Polri saat ini, belum optimal mengingat masih adanya berbagai faktor-faktor yang menjadi kendala dalam proses penyidikan tindak pidana korupsi tersebut.Faktor-faktor yang mempengaruhi dari aspek substansi hukum terutama substansi hukum formil yang multitafsir dalam rumusan delik korupsi. Aspek struktur hukum terutama terkait kelembagaan penyidik yang belum integral, dengan system koordinasi yang belum sinergis dan harmonis, sedangkan aspek kultur hukum terutama belum terbangunnya dukungan partisipasi masyarakat anti korupsi dalam upaya pemberantasan korupsi. Konsep penyidikan Polri yang ideal di masa mendatang adalah terbangunnnya sistem hukum baik aspek substansi, struktur maupun kultur hukum yang mendukung pemberantasan korupsi. Aspek substansi hukum, yang ideal adalah substansi yang secara tegas merumuskan delik korupsi sebagai delik formil dan tanpa multitafsir., dan substansi hukum formil yang mengintegrasikan system penyidikan tindak pidana korupsi. Aspek struktur hukum, yaitu terbangunnya institusi penyidikan yang integral, dengan system koordinasi yang sinergis dan harmonis dengan akuntabilitas yang tinggi, sedangkan aspek kultur hukum yaitu terbangunnya budaya anti korupsi, kemitraan polri dengan masyarakat serta partisipasi aktif masyarakat anti korupsi dalam mendukung pemberantasan tindak pidana korupsi.
\end{abstract}

\section{Kata Kunci : Konsep Penyidikan; Pemberantasan Korupsi; Penyidik Polri; Sistem Hukum}

\footnotetext{
${ }^{1}$ Mahasiswa Program Studi Magister IImu Hukum UNDIP

2 Penulis Kedua, Penulis Koresponden
} 


\section{A. PENDAHULUAN}

\section{Latar Belakang}

Masalah Korupsi ${ }^{3}$ bukan saja sebagai masalah yang dihadapi oleh suatu bangsa atau negara, tetapi korupsi adalah merupakan masalah yang dihadapi oleh umat manusia karena dampak yang ditimbulkan oleh kejahatan ini, bukan saja kerugian dari aspek ekonomi, tetapi hampir semua aspek kehidupan dipengaruhi baik sosial, budaya, politik dan keamanan. ${ }^{4}$ Masalah korupsi sebenarnya bukanlah masalah baru di Indonesia, karena telah ada sejak era tahun 1950 an. Berbagai kalangan

\footnotetext{
${ }^{3}$ Istilah korupsi berasal dari perkataan latin "coruptio" atau "corruptus" yang berarti kerusakan atau kebobrokan. Lihat Focus Andrea dalam Martiman Prodjohamidjojo, 2001, Penerapan Pembuktian terbalik dlam Delik Korupsi (UU No. 31 tahun 1999), Cetakan 1, Mandar Maju : Bandung, hal : 7). Menurut Lubis, M., dan Scoot, J.C. dalam pandangannya tentang korupsi disebutkan bahwa, korupsi dalam arti hukum adalah tingkah laku yang menguntungkan kepentingan diri sendiri dengan merugikan orang lain, oleh para pejabat pemerintah yang langsung melanggar batas-batas hukum atas tingkah laku tersebut, sedangkan menurut norma-norma pemerintah dapat dianggap korupsi apabila hukum dilanggar atau tidak dalam bisnis tindakan tersebut adalah tercela". lihat Lubis, M., dan Scoot, J.C.1993, Korupsi Politik, Yayasan Obor Indonesia : Jakarta, hal : 19)

${ }^{4}$ Menurut Barda Nawawi Arif bahwa Korupsi sangat menjadi sulit diberantas karena berkaitan erat dengan kompleksitas masalah lain seperti :. "Masalah sikaf mental/moral, masalah pola/sikap hidup dan budaya sosial, masalah kebutuhan/tuntutan ekonomi dan struktur/sistem ekonomi, masalah lingkungan hidup/sosial dan kesenjangan sosial-ekonomi, masalah struktur/budaya politik, masalah peluang yang ada di dalam mekanisme pembangunan atau kelemahanbirokrasi/prosedur administrasi (termasuk sistem pengawasan) di bidang keuangan dan pelayanan umum". Lihat Barda Nawawi Arief, 1997, Beberapa Pokok Pemikiran Kebijakan Penanggulangan Tindak Pidana Korupsi, Makalah yang disampaikan dalam seminar sehari tentang Mencari Solusi dan Modelmodel Pemberantasan Korupsi, Kolusi dan Manipulasi Di Lembaga Penegakan Hukum Indonesia, di Semarang pada tanggal 13 Agustus 1997: 4)..
}

menilai korupsi telah menjadi bagian dari kehidupan, menjadi suatu sistem dan menyatu dengan penyelenggaraan pemerintah negara. Berawal dengan keluarnya Peraturan No PRT/PM06/1957 tentang Pemberantasan Korupsi dan PRT/PERPU/013/1958 tentang Pengusutan, Penuntutan dan Pemeriksaan Perbuatan Korupsi dan Pemilikan Harta Benda dari Kepala Staf Angkatan Darat selaku penguasa perang pusat Angkatan Darat. Selain itu juga terdapat UU yang mengatur tentang tindak pidana korupsi yang kemudian secara berturut-turut mengalami perubahan sebanyak 4 (empat) kali. Yang pertama adalah PERPU NO 24 Tahun 1960 tentang Pengusutan, penuntutan, dan pemeriksaan Tindak Pidana Korupsi berubah menjadi UU No 1 Tahun 1961 yang kemudian berubah untuk kedua kalinya menjadi UU No 3 Tahun 1971 tentang Pemberantasan Tindak Pidana Korupsi, kemudian berubah untuk ketiga kalinya menjadi UU No 31 tahun 1999 tentang Pemberantasan Tindak Pidana Korupsi dan yang keempat disempurnakan lagi menjadi UU No. 20 Tahun 2001 tentang Perubahan atas UU No 31 tahun 1999 tentang Pemberantasan Tindak Pidana Korupsi.

Pertimbangan utama lahirnya Komisi Pemberantasan Korupsi (KPK) sebagaimana dirumuskan dalam konsideran UU No. 30 Tahun 2002 khususnya huruf b menjelaskan bahwa "lembaga pemerintah yang menangani perkara tindak pidana korupsi belum berfungsi secara 
efektif dan efisien dalam memberantas tindak pidana korupsi.

Perkembangan penegakan hukum pidana saat ini, menunjukkan bahwa munculnya lembagalembaga penyidik lainnya di luar Penyidik Kepolisian Negara Republik Indonesia, menjadi semakin banyak dan cenderung berdiri sendirisendiri.Oleh karena itu, selain berpotensi menimbulkan tumpang tindih kewenangan, juga berpotensi menimbulkan konflik antar penyidik.Disparitas lembaga penyidik tersebut menunjukkan tidak adanya integralisasi yang sinergis dan harmonis, sehingga berdampak pada tidak efektifnya upaya penyidikan tindak pidana itu sendiri. Penyidik Kepolisian Negara Republik Indonesia yang secara konstitusional sejak awal pembentukan Negara ini telah diletakkan tanggungjawab kewenangan di bidang penegakan hukum khususnya penyidikan terhadap tindak pidana korupsi, secara kelembagaan sangat kuat karena memiliki sumber daya manusia dan infrastruktur di seluruh wilayah Indonesia. Oleh karena itu, harapan untuk memberantas korupsi di negara Indonesia ini, seharusnya memperkuat Kepolisian secara kelembagaan khususnya yang berperan dalam proses penyidikan tindak pidana korupsi.

Permasalahan yang timbul ketika harapan dan arah kebijakan pemberantasan korupsi oleh penyidik Polri tidak diikuti dengan pembangunan sistem penyidikan yang baik atau konsep yang luar biasa (extra ordinary measure). Terutama jika dikaji dari sudut pandang system hukum baik dari aspek substansi hukum, struktur hukum maupun kultur hukum, maka sistem penegakan hukum oleh Polri belum dapat menjamin terwujudnya pemberantasan korupsi yang optimal.

Tidak adanya upaya untuk memperkuat posisi Penyidik Kepolisian Negara Republik Indonesia dalam proses pemberantasan tindak pidana korupsi, berdampak pada tidak efektifnya upaya pemberantasan tindak pidana korupsi itu sendiri.

\section{Permasalahan}

Permasalahan yang diajukan dalam penelitian ini adalah sebagai berikut :

1. Mengapa Konsep Penyidikan Tindak pidana Korupsi oleh Polri saat ini belum mampu mengefektifkan upaya pemberantasan korupsi?

2. Bagaimana konsep penyidikan tindak pidana korupsi oleh Polri yang diharapkan, sehingga mampu mengefektifkan upaya pemberantasan tindak pidana korupsi?

\section{B. METODE PENELITIAN}

Jenis penelitian yang dilakukan adalah penelitian hukum normatif, yaitu penelitian hukum dengan melakukan abstraksi melalui proses deduksi dari norma hukum positif yang berlaku, yang berupa sistematisasi hukum dan sinkronisasi hukum baik secara vertikal maupun horizontal terhadap peraturan perundang-undangan yang 
terkait dengan penyidikan tindak pidana korupsi oleh Kepolisian Negara Republik Indonesia.

Penelitian ini selain menggunakan data primer yang diperoleh langsung dari sumber penelitian untuk dijadikan bahan pertimbangan dan analisis terhadap obyek penelitian. Data primer digunakan untuk menguji konsep-konsep yang diteliti, guna memperkuat argumentasi hukum yang dibangun dalam penelitian ini.

Pendekatan yang digunakan dalam penelitian ini adalah pendekatan manajemen strategik dan pendekatan kualitatif, dimana peneliti akan menghubungkannya antara bahan hukum primer dan bahan hukum sekunder, kemudian melakukan analisis dan abstraksi terhadap bahan hukum primer untuk merumuskan suatu konsep penyidikan yang terintegratif dalam proses penegakan hukum terhadap tindak pidana korupsi oleh Kepolisian Negara Republik Indonesia.

\section{HASIL PENELITIAN DAN PEMBAHASAN}

\section{A. Konsep Penyidikan Polri Dalam Penanganan Tipikor Saat Ini}

Pada era Soeharto (1965 - 1998), yang gagal mengantisipasi disintegrasi pada administrasi kenegaraan yang diwarnai dengan peningkatan KKN dengan 3 (tiga) fenomena sosial yaitu pertama, kerjasama antara pimpinan militer dengan para pengusaha/ konglomerat, kedua keterlibatan para pengusaha pribumi termasuk koperasi,
BUMN yang dikontrol penuh oleh militer atau dalam format civil militery coalition yang lebih populer dengan pemerintahan dwi fungsi $A B R I$ dan ketiga, lemahnya kontrol pemerintahan terhadap perkembangan lebralisasi ekonomi dengan intervensi barat yang sangat kuat terhadap perkembangan ekonomi domestik yang menjadi semakin potensial dengan perbuatan $\mathrm{KKN}{ }^{5}$

Kecenderungan prilaku koruptif selanjutnya semakin berkembang, dengan cepat menyebar hampir ke semua sektor kehidupan berbangsa dan bernegara. Permasalahan Korupsi bukan hanya pada tingkat nasional tetapi telah menjadi masalah lintas negara atau transnasional yang ditandai dengan sebab musabab tipologi, bentuk, jenis dan modus operandi yang beragam serta sewaktu-waktu dapat tumbuh secara dinamis.Gambaran umum tentang prilaku korupsi cukup besar dalam suatu penelitian di New South Wales, Australia yang dilaksanakan oleh Independent Commision Against Corruption (Komite Anti Korupsi yang Independen) komisi tersebut melakukan identifikasi pandangan atas prilaku pejabat

5 Ilyas, H. Y., 2004, Korupsi Dalam Perspektif Agama-agama Remidid Kutub, Makalah yang disampaikan pada diskusi dan ceramah agama yang dilaksanakan di Klaten Jawa Tengah tanggal 27 Juli 2004, Yogyakarta, hal X. 
Jurnal Law Reform

Volume 11, Nomor 2, Tahun 2015

publik yang korupsi dan faktor-faktor yang menghalangi tindakan pemberantasan $\mathrm{KKN} .{ }^{6}$

Subyek (pelaku) dari dua definisi mengenai penyelidikan dan penyidikan tersebut adalah penyelidik dan penyidik. Berdasarkan pada ketentuan Pasal 1 angka 3 dan 4 UU No. 8 Tahun 1981 tentang Hukum Acara Pidana, maka penyidik adalah Pejabat Kepolisian Negara Republik Indonesia. Selanjutnya yang dimaksud penyidik menurut ketentuan Pasal 1 butir 1 UU No. 8 Tahun 1981 tentang Hukum Acara Pidana yaitu bahwa Penyidik adalah pejabat polisi negara Republik Indonesia atau pejabat pegawai negeri sipil tertentu yang diberi wewenang khusus oleh undang-undang untuk melakukan penyidikan.

\section{Eksistensi Penyidik Polri}

a. Sumber Daya Manusia Penyidik Polri

b. Anggaran Penyidikan Tipikor

c. Sarana dan Prasarana

\section{Faktor yang Mempengaruhi}

Menurut Komisi IV DPR RI, terdapat indikasi yang menyebabkan meluasnya korupsi di Indonesia, yakni:?

1. pendapatan atau gaji yang tidak mencukupi,

2. penyalahgunaan kesempatan untuk memperkaya diri,

6 Pope, J., 2003, Strategi Memberantas Korupsi, Yayasan Obor Indonesia : Jakarta, hal 31.

${ }^{7}$ Pidato Kenegaraan Presiden RI tanggal 16 Agustus 1970, yang dikutip dari Nurdjana, I.G.M. 2010, op. Cit. Hlm. 32
Program Studi Magister Ilmu Hukum Fakultas Hukum Universitas Diponegoro

3. penyalahgunaan kekuasaan untuk memperkaya diri.

Salah satu faktor yang menyebabkan berkembangnya korupsi adalah lemahnya penegakan hukum terhadap tindak pidana korupsi itu sendiri.Sistem penegakan hukum sendiri terdapat unsur-unsur yang mendukung terwujudnya tujuan penegakan hukum terhadap tindak pidana korupsi.salah satu unsur yang sangat penting dalam sistem penegakan hukum pidana adalah penyidik yang pada tahap penyidikan berupaya mengkonstruksikan perkara dengan mengumpulkan buktibukti dan menangkap pelaku korupsi yang selanjutnya menjadi landasan bagi Jaksa Penuntut Umum dan Hakim untuk melaksanakan tugas penegakan hukum.

\section{Kendala-kendala}

Menurut Ramelan ${ }^{8}$, kendala yang bersifat non teknis yuridis dalam pengungkapan kasus-kasus tindak pidana korupsi adalah :

a. kompleksitas perkara sering memerlukan pengetahuan yang komprehensif. Sebagai contoh dalam mengahadapi kasus korupsi di bidang perbankan, maka selain harus mengatahui dan memahami

\footnotetext{
8 Ramelan, 2004, Penegakan hukum Tindak Pidana Korupsi dan Upaya Kejaksaan Memenuhi Ekspetasi Publik, Makalah seminar dalam rangka Dies Natalis Universitas Sebelas Maret ke 28, Surakarta, hal : 9.
} 
pengetahuan di bidang pidana, aparat penegak hukum juga harus mengetahui dan memahami pengetahuan di bidang keuangan dan Ialu lintas moneter. Dalam hal ini seringkali dibutuhkan bantu an dari pihak yang ahli untuk dimintai pendapatnya sebagai saksi ahli.

b. Tindak pidana korupsi pada umumnya melibatkan sekelompok orang yang saling menikmati keuntungan dari tindak pidana tersebut. Dengan demikian mereka akan saling bekerja sama untuk saling menutupi perbuatan mereka. Hal ini menyulitkan aparat penegak hukum dalam mengungkap buktibukti yang ada .

c. Waktu terjadinya tindak pidana korupsi umumnya baru terungkap setelah tenggang waktu yang cukup lama. Hal ini menyulitkan pengumpulan atau merekonstruksi keberadaan bukti-bukti yang sudah terlanjur dihilangkan atau dimusnahkan. Di samping itu para saksi atau tersangka yang sudah terlanjur pindah ketempat lain juga berperan untuk menghambat proses pemeriksaan .

d. Dengan berbagai upaya, pelaku tindak pidana korupsi telah menghabiskan uang hasil korupsi dengan cara menggunakannya sendiri atau dengan sengaja mengalihkannya dengan bentuk yang lain sehingga akan mempersulit pelacakan uang hasil korupsi.

\section{B. Konsep Penyidikan Tipikor Polri Yang Ideal}

\section{Substansi Hukum}

a. Substansi Hukum Internasional

Komitmen dunia internasional untuk memberantas korupsi dan jaringan kerjasama internasional, saat ini belum dimanfaatkan secara maksimal dalam proses penyidikan di Indonesia, karenanya belum dirumuskan mekanisme tehnis dan strategi kerjasama dan sistem koordinasi penyidikan internasional terutama dalam penanggulangan dan pemberantasan korupsi. Yang digunakan saat ini, adalah mekanisme kerjasama melalui Interpol yang masih dipengaruhi oleh perjanjian ekstradisi antar Negara.

b. Substansi Hukum Materiil

Peraturan pertama yang dibentuk oleh pemerintahdalam rangka pemberantasan korupsi adalah Peraturan Penguasa Militer 
Nomor.Prt/PM-06/1957 tanggal9 April 1957.

Selanjutnya diterbitkan peraturan Penguasa Perang Pusat Kepala Staf Angkatan Darat tanggal16 April 1958 No. Prt/Peperpu/013/1958 tertanggal 16 April 1958 tentang Pengusutan, Penuntutan dan Pemeriksaan Perbuatan Korupsi Pidana dan Pemilikan Harta Benda, serta Peraturan Penguasa Perang Pusat Kepala Staf Angkatan Laut No. Prt/Z.I./7 tertanggal 17 April 1958.Menurut kedua peraturan tersebut, perbuatan tindak pidana korupsi pada saat itu digolongkan menjadi dua macam, yaitu Perbuatan Korupsi Pidana dan Perbuatan Korupsi Bukan Pidana.Akan tetapi dalam kedua peraturan tersebut tidak dijelaskan secara lebih lanjut mengenai pengertian kedua hal tersebut.

Oleh karena itu, dengan mengacu pada penjelasan yang terdapat dalam Perpu No. 24 Tahun 1960 tentang Pengusutan, Penuntutan Dan Pemeriksaan Tindak Pidana Korupsi ${ }^{9}$, yang dapat dikatagorikan sebagai Perbuatan Korupsi Pidana adalah perbuatan korupsi yang didalamnya terdapat unsur-unsur kejahatan

9 (Lembaran Negara Republik Indonesia Tahun 1960 Nomor 72, Tambahan Lembaran Negara Republik Indonesia Nomor 2011). sehingga berdasarkan hal tersebut dapat dipidana dengan hukuman badan dan/atau denda yang cukup berat disamping perampasan harta benda hasil korupsinya. Sedangkan yang dikatagorikan sebagai Perbuatan Korupsi Bukan Pidana, adalah perbuatan korupsi yang didalamnya terdapat unsur perbuatan melawan hukum.Perbuatan korupsi ini tidak diancam dengan hukuman pidana, melainkan Pengadilan Tinggi yang mengadilinya atas gugatan Badan Koordinasi Pemilik Harta Benda, dapat merampas harta benda hasil korupsi tersebut.

\section{Struktur Hukum}

Konsep penyidikan yang ideal dari aspek struktur hukum dalam pemberantasan korupsi adalah sebagai berikut :

a. Pendidikan hukum dan penelitian hukum memadai bagi penyidik. Dilakukan secara priodik dan terstruktur serta dinamis mengikuti perkembangan kejahatan korupsi itu sendiri.

b. Organisasi profesi hukum, memiliki visi dan misi yang sama dalam pemberantasan tindak pidana korupsi. Dengan demikian, dalam prosedur dan sistem kerja yang 
dibangun mendukung proses penegakan hukum yang dilakukan oleh penyidik.

C. Orientasi kerja birokrasi penyidik Polri, tidak ditentukan dengan target tertentu atau ABS, akan tetapi mengacu pada due procces of law dengan mengedepankan profesionalisme, transparansi dan akuntabiltas.

d. Etika profesi hukum tetap harus dikedepankan dengan didasarkan pada konsep civilian police (Polisi sipil) yang humanis dan religius.

e. Dana pembangunan di bidang hukum memadai serta mengakomodir semua perkara yang ditangani.

f. Koordinasi antar aparat penegak hukum, sinergis dan harmonis dalam suatu sistem yang integral.

g. Koordinasi dengan instansi pemerintah lainnya juga terbangun secara sinergis dan harmonis, namun tetap independen (tanpa interpensi).

h. Sarana dan prasarana yang memadai hingga ke pelosok-pelosok daerah di seluruh Indonesia.

i. Tidak ada tumpang tindih kewenangan antar penyidik, tetapi institusi penyidik integral, sinergis dan harmonis.

j. Kesatuan Penafsiran masing-masing institusi penyidik, dalam satu visi dan misi yang integral, saling melengkapi dan saling mendukung.

\section{Kultur Hukum}

Kondisi kultur hukum yang ideal bagi Penyidikan tindak pidana korupsi oleh Kepolisian Negara Republik Indonesia menurut pandangan penulis adalah :

a. Kondisi kesadaran hukum masyarakat yang mendukung pemberantasan korupsi, tidak permissif terhadap prilaku koruptif, tapi ikut berpartisipasi dalam pemberantasan korupsi.

b. Pemberdayaan para tokoh sentral di daerah melalui penerapan konsep Polmas sesuai dengan kearifan lokal daerah setempat, diarahkan untuk mendukung penegakan hukum pemberantasan korupsi.

C. Nilai-nilai budaya dalam struktur budaya di daerah, diaktualisasikan dalam membangun sistem demokrasi yang sehat, guna mendukung penegakan hukum terhadap tindak pidana korupsi, dan terwujud budaya malu korupsi. 
Jurnal Law Reform

Volume 11, Nomor 2, Tahun 2015
Program Studi Magister Ilmu Hukum Fakultas Hukum Universitas Diponegoro d. Terbangun nilai-nilai kedekatan, partisipatif dan inisiatif masyarakat di daerah-daerah, dalam mendukung penyidikan Polri guna memberantas tindak pidana korupsi.

e. Tingkat kematangan politik masyarakat dalam suasana demokrasi, terkendali dan tidak mengintervensi penyidikan tindak pidana korupsi.

f. Perubahan perilaku masyarakat (social behaviour) yang mengglobal tanpa batas (borderless), tetap menjadi normanorma hukum sebagai filter dalam kehidupan berbangsa dan bernegara.

g. Krisis ekonomi, sosial dan politik tidak mempengaruhi penegakan hukum dalam pemberantasan korupsi.

Kondisi tersebut membutuhkan kerjasama di semua elemen, juga melibatkan partisipasi masyarakat dalam upaya sistem peradilan pidana yang lebih baik di masa datang.

\section{KESIMPULAN DAN SARAN}

\section{A. Kesimpulan}

1. Bahwa konsep penyidikan Polri dalam rangka pemberantasan tindak pidana korupsi pada saat ini, belum optimal mengingat masih adanya berbagai factorfaktor yang menjadi kendala dalam proses penyidikan tindak pidana korupsi tersebut. Faktor-faktor yang mempengaruhi dari aspek substansi hukum terutama terkait dengan substansi hukum formil yang memberikan multitafsir dalam rumusan delik korupsi. Aspek struktur hukum terutama terkait dengan kelembagaan penyidik yang belum integral, dengan system koordinasi yang belum sinergis dan harmonis, sedangkan aspek kultur hukum terutama belum terbangunnya dukungan partisipasi masyarakat anti korupsi dalam upaya pemberantasan korupsi.

2. Bahwa konsep penyidikan Polri yang ideal di masa mendatang adalah terbangunnya sistem hukum baik aspek substansi, struktur maupun kultur hukum yang mendukung pemberantasan korupsi. Aspek substansi hukum, yang ideal adalah substansi yang secara tegas merumuskan delik korupsi sebagai delik formil dan tanpa multitafsir, dan substansi hukum formil yang mengintegrasikan system penyidikan tindak pidana korupsi. Aspek struktur hukum, yaitu terbangunnya institusi penyidikan yang integral, dengan system koordinasi yang sinergis dan harmonis dengan 
akuntabilitas yang tinggi, sedangkan aspek kultur hukum yaitu terbangunnya budaya anti korupsi, kemitraan polri dengan masyarakat serta partisipasi aktif masyarakat anti korupsi dalam mendukung pemberantasan tindak pidana korupsi.

\section{B. Saran}

Sebagai saran rekomendasi dari penulis untuk melakukan rekonseptualisasi penyidikan Polri dalam pemberantasan tindak pidana korupsi, adalah sebagai berikut

1. Perlunya dilakukan perubahan baik reformulasi maupun rekonstruksi pada mekanisme dalam Hukum Acara Pidana baik KUHAP maupun UU yang terkait dengan Tindak Pidana Korupsi dengan semangat integralisasi kelembagaan penyidik, dan system koordinasi dan pengawasan penyidik yang dinergis dan harmonis, serta meletakkan prosedur dan metode penyidikan tindak pidana korupsi yang akuntabel.

2. Perlunya merumuskan konsep pemberantasan korupsi dengan satu visi dan misi yang mengakomodir secara integral seluruh konsep pemberantasan tindak pidana korupsi pada semua instansi pada umumnya dan semua penegak hukum khususnya, serta antara konsep penegakan hukum dengan konsep pemberdayaan masyarakat anti korupsi.

\section{DAFTAR PUSTAKA}

Ilyas, H. Y., 2004, Korupsi Dalam Perspektif Agama-agama Remidid Kutub, Makalah yang disampaikan pada diskusi dan ceramah agama yang dilaksanakan di Klaten Jawa Tengah tanggal 27 Juli 2004, Yogyakarta.

Lubis, M., dan Scoot, J.C.1993, Korupsi Politik, Yayasan Obor Indonesia : Jakarta

Nawawi Arief, Barda, 1997, Beberapa Pokok Pemikiran Kebijakan Penanggulangan Tindak Pidana Korupsi, Makalah yang disampaikan dalam seminar sehari tentang Mencari Solusi dan Model-model Pemberantasan Korupsi, Kolusi dan Manipulasi Di Lembaga Penegakan Hukum Indonesia, di Semarang pada tanggal 13 Agustus 1997.

Nurdjana, I.G.M. 2003, Wewenang Polri dalam Penindakan KKN, Yogyakarta.

Pope, J., 2003, Strategi Memberantas Korupsi, Yayasan Obor Indonesia : Jakarta.

Ramelan, 2004, Penegakan hukum Tindak Pidana Korupsi dan Upaya Kejaksaan Memenuhi Ekspetasi Publik, Makalah seminar dalam 
Jurnal Law Reform

Volume 11, Nomor 2, Tahun 2015

rangka Dies Natalis Universitas Sebelas Maret ke 28, Surakarta.

\section{PERATURAN PERUNDANG-UNDANGAN}

Undang-Undang No. 1 Tahun 1961 tentang

Penetapan Semua Undang-Undang

Darurat Dan Semua Peraturan Pemerintah

Pengganti Undang-Undang Yang Sudah

Ada Sebelum Tanggal 1 Januari 1961

Menjadi Undang-Undang (Lembaran

Negara Republik Indonesia Tahun 1961

Nomor 3, Tambahan Lembaran Negara

Republik Indonesia Nomor 2124).

Undang-Undang No. 3 Tahun 1971 tentang

Pemberantasan Tindak Pidana Korupsi

(Lembaran Negara Republik Indonesia

Tahun 1971 Nomor 19, Tambahan

Lembaran Nomor 2958).

Undang-Undang No. 8 Tahun 1981 tentang Hukum

Acara Pidana (Lembaran Negara Republik Indonesia Tahun 1981 Nomor 76,

Tambahan Lembaran Negara Nomor 3209).

Undang-Undang No. 31 Tahun 1999 tentang

Pemberantasan Tindak Pidana Korupsi

(Lembaran Negara Republik Indonesia

Tahun 1999 Nomor 140, Tambahan

Lembaran Negara Nomor 3874).
Program Studi Magister Ilmu Hukum

Fakultas Hukum Universitas Diponegoro

Undang-Undang No. 20 Tahun 2001 tentang Perubahan atas Undang-undang Nomor 31 Tahun 1999 tentang Pemberantasan Tindak Pidana Korupsi (Lembaran Negara Republik Indonesia Tahun 2001 Nomor 134, Tambahan Lembaran Negara Nomor 4150).

Undang-UndangNo.30Tahun2002 tentangKomisi PemberantasanKorupsi(LembaranNegaraR epublik IndonesiaTahun2002Nomor137, TambahanLembaranNegaraRepublik IndonesiaNomor4250).

Perpu No. 24 Tahun 1960 tentang Pengusutan, Penuntutan Dan Pemeriksaan Tindak Pidana Korupsi (Lembaran Negara Republik Indonesia Tahun 1960 Nomor 72, Tambahan Lembaran Negara Republik Indonesia Nomor 2011). 